\title{
Development of Eco-Friendly Solar Photovoltaic Insect Light Trap for Pest Control
}

\author{
A.M. Gavhande*, S.R. Kalbande and V.P. Khambalkar \\ Department of Unconventional Energy Sources and Electrical Engineering, Dr. Panjabrao \\ Deshmukh Krishi Vidyapeeth, Akola (MS) 444104, India \\ *Corresponding author
}

\begin{tabular}{|l|}
\hline Ke y w o r d s \\
Solar Photovoltaic, \\
Insect Light Trap, \\
Ultra violet-A blue, \\
Efficiency, Benefit \\
Cost Ratio \\
\hline Article Info \\
\hline Accepted: \\
04 June 2019 \\
Available Online: \\
10 July 2019
\end{tabular}

A B S T R A C T

A solar photovoltaic insect light trap was developed consisted of $10 \mathrm{Wp} \mathrm{SPV}$ panel, $12 \mathrm{~V}$; 7 Ah lead acid battery, charge controller, dusk to down electrical circuit and adjustable stand. As per design calculations the trap was fabricated in the workshop. The performance of solar photovoltaic insect light trap was taken in the farmer's cotton crop field Vazegaon, Dist. Akola (Maharashtra), for finding out the efficiency of the developed solar insect light trap and insect trapping during night hours. The average values of ambient temperature, wind velocity, panel temperature, solar intensity, panel output, panel efficiency, panel voltage, panel current, exergy efficiency of panel and battery voltage in different colour light trap viz., blue, yellow and UV-A blue were recorded. The total number of insects caught in blue, yellow and UV-A blue colour light were 6820,8199 and 19872 , respectively during the experimentation. The order wise and daily distribution of insects in UV-A blue colour light, the highest population of Lepidoptera insects was observed. It could be inferred that the solar insect light trap was technically as well as economically feasible.

\section{Introduction}

The demand for energy is growing day by day in the whole world. The Conventional energy sources like coal and petroleum are limited. Renewable energy resources will play an important role in the future. Agriculture is a principal occupation in India and more than 70 $\%$ peoples are involved in agriculture. Insect pests are the major problem to the farmers greatly reducing their income by destroying the field crops. There are many preventions and exterminations for pest problems, such as physical, biological, chemical and mechanical methods are controlling the insect pests. This causes plant residue which is dangerous for consumers and when consuming the fruits and vegetables gives us major problems to the health (Brimapureeswaran, 2016). The main or major phototropic insect pests of cotton that cause economic loss to this crop are cotton jassid, cotton whitefly, Armyworm, Cotton 
Mealy Bug, American bollworm, Pink bollworm and other (Muhammad, 2017).

Light becomes visible to insects around the yellow part of the spectrum and ends at ultraviolet light. (Ashfaq et al., 2005) Reducing and controlling the pest population using light traps is an age old practice. Though several models and designs of insect light trap are available but according to (Reddy et al., 2010) solar powered trap with collecting net developed which has not dependent on any other source like wind power, mechanical power, fuel and electricity. This device operates automatically, turning on the light during night hours and turned off before sunrises. Vidarbha and Marathwada regions of Maharashtra are staring at huge losses owing to a pest (bollworm) attack on the cotton crop, across at least eight lakh hectares of land in 20 districts.

More than $96 \%$ farmers use BT cotton seeds, which were supposed to be averse to the attack of bollworm and thus cotton production was reduced drastically. The farmers are using costly pesticides but the bollworm was found resistant to the chemicals available in the market.

Hence the integrated pest management techniques for pest control use of pheromone trap, yellow sticky trap, electrically operated light trap etc. was suggested. One of the limitations of electrically operated light trap use on the farmer's field in the unavailability of electricity/grid on each and every field. In Indian villages, availability of electricity is a major constrain and almost absent in remote villages (Bhamre et al., 2005) along with higher cost of electricity or electrically based light traps.

Keeping these points in view, developed ecofriendly solar operated insect light trap for control pest population.

\section{Materials and Methods}

\section{Location and site}

Akola is located at latitude $20.7^{\circ}$ North and longitude $77.07^{\circ}$ East. It is situated at an altitude of $287 \mathrm{~m}$ to $316 \mathrm{~m}$ above mean sea level. The experiment was conducted at the field of Vazegaon, Taluka Balapur Dist. Akola during March 2018.

\section{Development of solar photovoltaic insect light trap}

This system is mainly consisted of solar panel, sealed lead acid battery, charge controller, relay circuit, LED light, bulb holding funnel, insect collecting chamber, battery box and adjustable three leg support base frame (Bera, 2015).

\section{Energy analysis}

The performance of a SPV module and battery was expressed in terms of their current, voltage and power output characteristic which is a function of solar radiation and module temperature, photovoltaic and exergy efficiency.

\section{Evaluation of solar insect light trap using different colour LED lights}

The experiment was conducted by using solar photovoltaic operated light trap with three colored LED having 5 Watt power rating bulb viz., blue, yellow, and UV-A blue. All three light traps were installed at 2 feet above the crop height and 30 meter apart from each other to let the insect to orient toward their most favorite colour.

Light traps were operated from $19.00 \mathrm{hrs}$ to $22.00 \mathrm{hrs}$ and $4.00 \mathrm{hrs}$ to $6.00 \mathrm{hrs}$ daily numbers of insects caught were recorded and the insects were separated order wise. 
Order wise comparison of the insects caught in the above mentioned light traps

The insects collected by the above mentioned light traps were sorted out order wise and tabulated to know the effect of light on the attraction of insect.

Economic feasibility of solar photovoltaic insect light trap

The economic feasibility of solar insect trap was calculated by using discount rate method.

Following different economic indicators were used for economic analysis of solar system under this study (El-Nashar, 2000):

Net present worth (NPW)

Benefit cost ratio ( $\mathrm{B} / \mathrm{C}$ ratio)

Payback period

\section{Results and Discussion}

Results obtained during experimentation are discussed in following subsection.

\section{Performance evaluation of solar insect light trap}

The comparative performance of solar photovoltaic insect light trap of the three colors LED light viz., blue, yellow and ultra violet-A blue were evaluated and the results obtained are discussed.

\section{Performance of solar photovoltaic system}

The variation in solar intensity and corresponding power, current, voltage, ambient temperature, panel temperature, panel efficiency and exergy efficiency with time was recorded for the consecutive days in March when solar insect light trap was kept in cotton field (Bhubneswari et al., 2011). From the above results Figure 4 shows that the power developed by SPV panel increased with respect to increase in solar radiation. It was revealed that, the power generated by selected solar panel was suitable for solar photovoltaic insect light trap.

The typical V-I characteristic's curve of solar panel is shown in Figure 5. It was revealed that, the selected panel is suitable in terms of current, voltage and power supply to the solar photovoltaic insect light trap.

The variation of solar intensity, ambient temperature and panel temperature developed with respect to time in solar panel is shown in Figure 6.

Figure 7 gives the variation in panel efficiency, exergy efficiency and solar intensity with respect to time (Fig. 1-3; Table 1).

Evaluations of light trap using different colour LED light for trapping phototrophic insects

Table 2 represents the percentage of the total number of insects caught in various coloured light traps. According to the percentage of insects collected, the lowest number of insects were attracted towards blue colour light i.e. $19.54 \%$. This finding is in accordance with Ashfaq et al., 2005 and Pate and Curtis (2011) who also found that the lowest numbers of insects were trapped in blue colored light among the various coloured lights tested. Ultra violet light attracted the highest number of $56.95 \%$ insects.

Yellow light was rated second in attracting the insects (23.49\%). Percentage of insects attracted towards different coloured light was computed separately and tabulated in Table 3 and shown in Figure 8.

Use of solar insect light trap for collecting harmful insect is one of the tool in IPM. 
Table.1 Details components of solar photovoltaic insect light trap

\begin{tabular}{|c|c|c|c|}
\hline S. N. & Components & Details & Specification \\
\hline 1 & Photovoltaic panel & $\begin{array}{l}\text { Multi crystalline Silicon Solar cells used in } \\
\text { the photovoltaic panel for the solar insect } \\
\text { light trap to generate sufficient voltage to } \\
\text { charge the battery with exposure to } \\
\text { sunlight }\end{array}$ & $10 \mathrm{Wp}$ \\
\hline 2 & Sealed lead acid battery & $\begin{array}{l}\text { Battery is a source of stored electrical } \\
\text { energy or it is called as storage cell battery, } \\
\text { means it can store electrical energy and } \\
\text { give whenever requires. }\end{array}$ & $12 \mathrm{~V} ; 7 \mathrm{Ah}$ \\
\hline 3 & Charge controller & $\begin{array}{l}\text { A charge control unit prevents the reverse } \\
\text { flow of current from battery to panel and } \\
\text { also protects battery from overcharging }\end{array}$ & $10 \mathrm{~A}$ \\
\hline 4 & Relay circuit & $\begin{array}{l}\text { relay is used to turn on by sunset and turn } \\
\text { off after sunrise and it is a continuous } \\
\text { operation }\end{array}$ & $12 \mathrm{~V}, 10 \mathrm{~A}$ \\
\hline 5 & LED light & $\begin{array}{l}\text { A 5-watt blue and yellow L.E.D. strip bulb } \\
\text { having } 3 \text { bulbs on each strip and total of } 30 \\
\text { bulbs were used. One } 5 \text {-watt ultra violet } \\
\text { light having } 16 \text { number bulbs on each line } \\
\text { and total } 48 \text { numbers of bulbs were joined } \\
\text { to make a single bulb. Hence to attract the } \\
\text { insect UV-A blue L.E.D. bulb, blue L.E.D. } \\
\text { bulb and yellow L.E.D. bulb were used }\end{array}$ & $5 \mathrm{~W}$ \\
\hline 6 & ON/OFF switch & It used to ON or OFF the complete system & \\
\hline 7 & Bulb holding funnel & $\begin{array}{l}\text { It was hanged over the stand with the help } \\
\text { of iron angle and holds the bulb assembly }\end{array}$ & $\begin{array}{l}\text { Upper dia.: } 30 \mathrm{~cm} \\
\text { Lower dia.: } 5 \mathrm{~cm}\end{array}$ \\
\hline 8 & Insect collecting chamber & $\begin{array}{l}\text { It acts as a collection unit for insect which } \\
\text { was hanged to the bulb holding funnel }\end{array}$ & Diameter: $38 \mathrm{~cm}$ \\
\hline 9 & Battery box & $\begin{array}{l}\text { It holds the battery, solar charge } \\
\text { controller, relay, ON/OFF switch, power } \\
\text { outlets and input in the same box. }\end{array}$ & $22 \mathrm{~cm} \times 18 \mathrm{~cm}$ \\
\hline 10 & $\begin{array}{l}\text { Adjustable three leg } \\
\text { support based frame }\end{array}$ & $\begin{array}{l}\text { It was provided with adjustable screw to } \\
\text { maintain the height of bulb according to } \\
\text { crop height }\end{array}$ & $\begin{array}{l}\text { Length: } 153 \mathrm{~cm} \\
\text { Height: } 98 \mathrm{~cm}\end{array}$ \\
\hline
\end{tabular}

Table.2 Percentage of insects attracted in different light trap

\begin{tabular}{|l|l|l|}
\hline S.N. & Colour of light & Insect population percent (\%) \\
\hline 1. & Ultra violet & 56.95 \\
\hline 2. & Yellow & 23.49 \\
\hline 3. & Blue & 19.54 \\
\hline
\end{tabular}


Table.3 Percentage of insects attracted in blue light, Yellow light and UV light

\begin{tabular}{|c|c|c|c|c|}
\hline \multirow{2}{*}{ S.N. } & \multirow{2}{*}{ Order } & \multicolumn{3}{|c|}{ Insect population percent (\%) } \\
\cline { 3 - 5 } & & Blue light & Yellow light & Ultraviolet light \\
\hline 1. & Hemiptera & 50.52 & 50.28 & 51.92 \\
\hline 2. & Lepidoptera & 44.36 & 44.77 & 41.00 \\
\hline 3. & Diptera & 4.85 & 4.72 & 6.96 \\
\hline 4. & Coleoptera & 0.24 & 0.21 & 0.10 \\
\hline
\end{tabular}

Table.4 Parameters used to analyses the economic feasibility of solar insect light trap

\begin{tabular}{|l|l|l|l|}
\hline S. N. & Costs & Two SPV light trap & One Electrical light trap \\
\hline 1. & Capital cost & 6000 & 3800 \\
\hline 2. & Maintenance Cost & 600 & 600 \\
\hline 3. & Electricity charge & Nil & 2856 \\
\hline
\end{tabular}

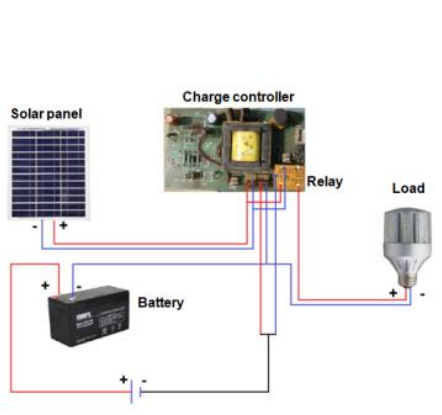

Fig.1 Circuit arrangement

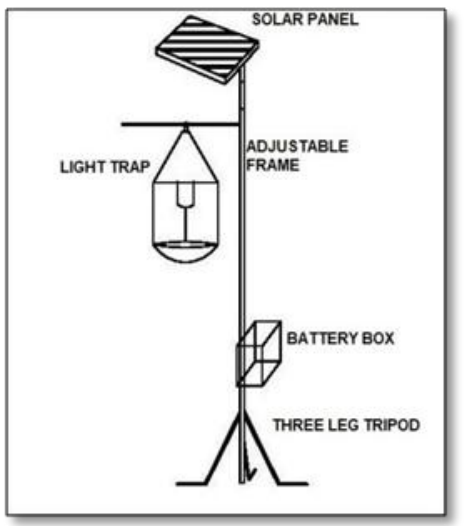

Fig.2 Solar insect light trap

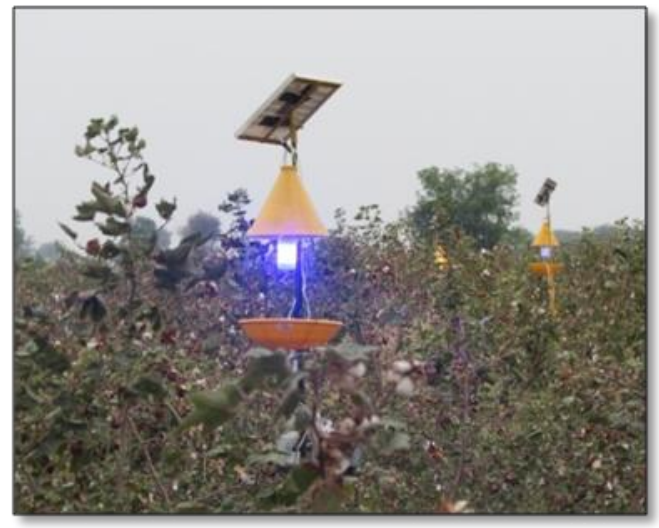

Fig.3 Field performance of SPV insect light trap

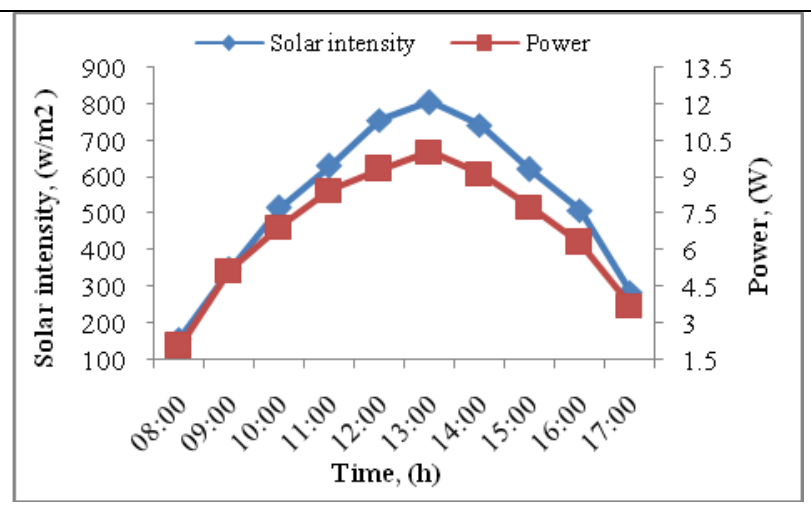

Fig.4 Variation in solar intensity and power output of solar panel with time

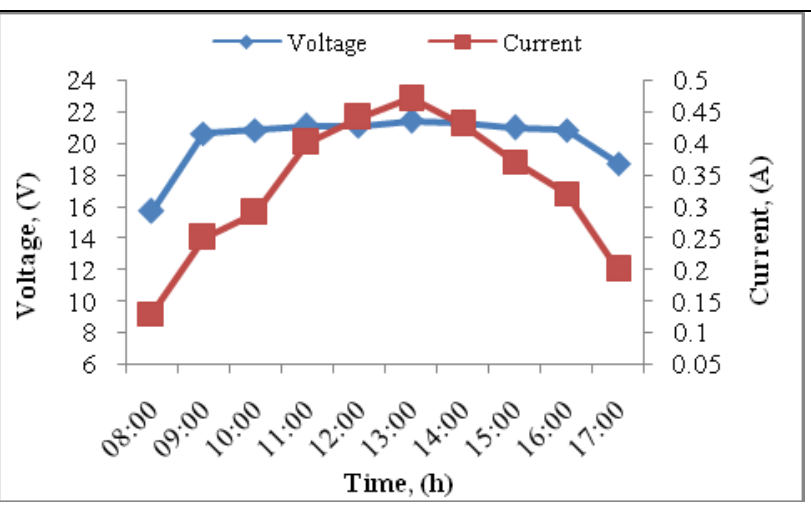

Fig.5 Variation in current and voltage of solar panel with time 


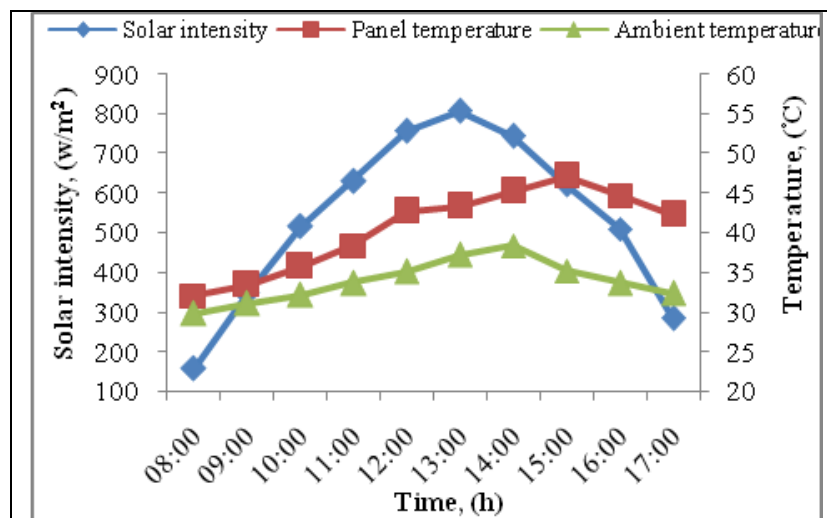

Fig.6 Variation in ambient temperature, panel temperature and solar intensity with time

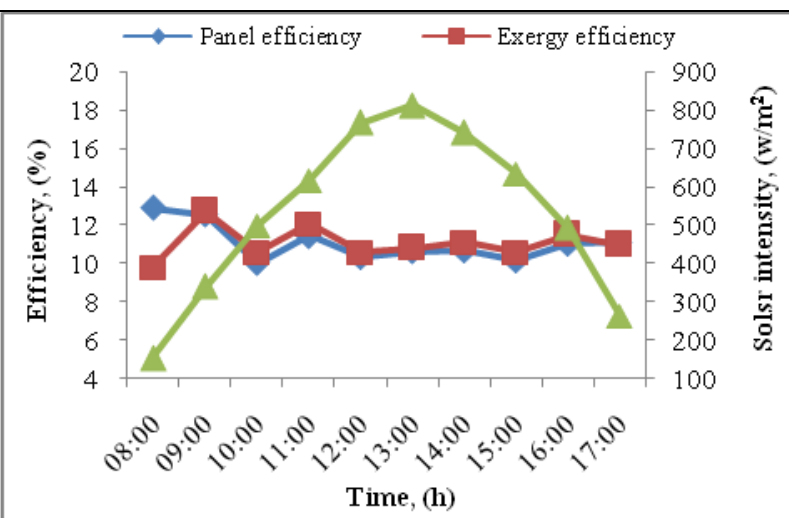

Fig.7 Variation in panel efficiency, exergy efficiency and solar intensity with time

Fig.8 Insects attracted in different coloured light trap

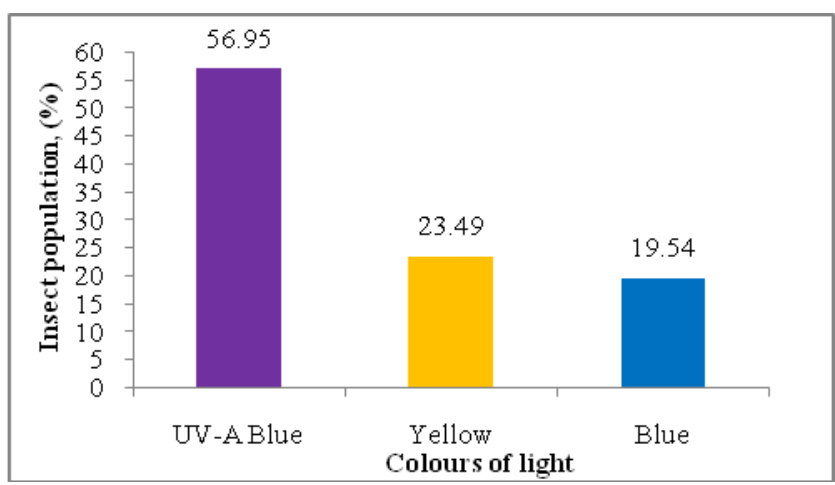

Among all three light traps, the performance of UV-A blue light insect trap was found better in terms of insect collected. Most of the harmful insects were attracted towards UV-A blue light and hence it is calculated that the use of UV-A blue light in solar insect trap is beneficial in integrated pest management practices (Bhamre et al., 2005).

\section{Economic feasibility of solar photovoltaic insect light trap}

The economic feasibility of the solar photovoltaic insect light trap was evaluated using discount cash flow (DCF) method (Table 4). The economic parameters are present worth of cost, present worth of benefit, net present value and payback period was determined.
The net present value for the 12 year of cash flow analysis was found to be Rs.9371.69. The benefit cost ratio of the financial system has been worked out for the cost and benefit involved over the period. The benefit cost ratio of the solar photovoltaic insect light trap was observed to be 1.93 with payback period of 2 year 1 month.

The maximum efficiency of $10 \mathrm{Wp}$ solar panel was found to be $14.25 \%$. The maximum working hours of SPV light trap was 10-13 hours. The battery was full charged in 6 hour with the help of SPV panel. The more insects were attracted by ultra violet coloured light trap rather than blue and yellow colored light trap. The area of coverage of UV-A blue light trap was found 2.5 acre per two traps. 
The solar insect light trap was found ecofriendly more effective for the control of different insect pests of all crops without any use of chemical pesticides in the agricultural fields in near future.

The economic analysis suggested that the solar photovoltaic insect light trap was economically viable and could be used for controlling the insect and pest population in IPM technique.

\section{References}

Ashfaq, M., Khan, Rashid A., Khan, M. A., Rasheed, F. and Hafeez, S. 2005. Insect orientation to various colour light in the Agricultural biomass of Faisalabad. Pak. Entomol. 27(1): 49-52.

Bera P.K. 2015. Development of a New Solar Light Trap Model and its Utilization as IPM Tool in Agriculture. Journal of Emerging Technologies and Innovative Research. 2(3): 549-554.

Bhamre, V., Sarkate, M.B., Wadnerkar, D.W. and Ramtake, R.T. 2005. A solar light Trap for monitoring and controlling of insect pests of cotton, In: National Conference on Applied Entomology, Udaipur, September 26-28, 2005. pp 2021.

Bhubaneswari P., Iniyanb S. and Ranko G. 2011. A review of solar photovoltaic technologies. Renewable and Sustainable Energy Reviews 15: 16251636.
Brimapureeswaran R., Nivas G., Meenatchi R., Sujeetha Alice R.P., Loganathan M. 2016. Development of a New Solar Light cum Glue Trap Model and its Utilization in Agriculture. In. J. of Emerging Technology and Innovative Engineering. 2(3): 37-41.

El-Nashar, Ali M., 2000. Economics of small solar-assisted multiple-effect stack distillation plants. Desalination 130, 201-215.

Muhammad S. (2017). Biological Parameters of Pink Bollworm Pectinophora gossypiella (Saunders) (Lepidoptera: Gelechiidae): A looming Threat for Cotton and its Eradication Opportunity. International Journal of Research in Agriculture and Forestry. Vol. 4(7): 2536.

Pate, J. and Curtis, A. 2001. Insects response to different wavelengths of light in New River state Park, Ash County, North Carolina. Field Biology and Ecology. 12(2): 4-8

Reddy H.L., Reddy A.V., Hemanth S. and Durga Prasad P.J. 2015. Modelling and Optimization of Solar Light Trap For "Reducing and Controlling" The Pest Population. In. J. of Engineering Technology, Management and Applied Sciences. 3(4): 224-234.

Srinivas M., S. Jayaraj. 2013. Energy and exergy analysis of a two pass photovoltaic thermal $(\mathrm{PV} / \mathrm{T})$ air heater. International Journal of Energy and Environment. Volume 4, Issue 3, pp. 467-480.

\section{How to cite this article:}

Gavhande, A.M., S.R. Kalbande and Khambalkar, V. P. 2019. Development of Eco-Friendly Solar Photovoltaic Insect Light Trap for Pest Control. Int.J.Curr.Microbiol.App.Sci. 8(07): 95101. doi: https://doi.org/10.20546/ijcmas.2019.807.013 